\title{
Breastfeeding and employed mothers in Ethiopia: legal protection, arrangement, and support
}

Ermiyas Mulu Kebede* ${ }^{*}$ and Benyam Seifu

\begin{abstract}
Background: Breastfeeding is the single, most cost-effective intervention to reduce worldwide child mortality. Women empowerment interventions have positive impacts on child and maternal nutritional, and health status. Women's employment and economic participation in Ethiopia have shown progress over the past three decades. However, consistent evidence indicated that maternal employment is often negatively associated with optimal breastfeeding in Ethiopia. The existence and enforcement of breastfeeding law, arrangement, and support in the workplace have vital roles in protecting employed mothers' ability and right to breastfeed upon return to work from maternity leave. This commentary compared the breastfeeding laws, policies, and arrangements in Ethiopia with international standards, recommendations, and evidence-based practices.

Workplace breastfeeding policies in Ethiopia: Public legislations of Ethiopia poorly protect the breastfeeding right of most new mothers. Ethiopian revised Labor Proclamation (No.1156/2019) incorporates most of the International Labour Organization maternity protection recommendations. However, it poorly safeguards breastfeeding rights and abilities of employed women. The provided maternity leave period is also shorter than the recommended exclusive breastfeeding duration. The revised Federal Civil Servant Proclamation of Ethiopia (NO.1064/2017) mandates the establishment of a nursery in government institutions where female civil servants could breastfeed and take care of their babies in a private room. Though, it protects only a small proportion of working mothers in Ethiopia, as majority women employed in the agriculture and informal economy sectors. So far, there are no notable workplace breastfeeding arrangements and support for employed mothers by employers and other initiatives. The ILO recommendation and experience of other middle income and low-income countries can be legal and practical grounds for establishment of breastfeeding-friendly workplace in Ethiopia.

Conclusions: The lack of workplace breastfeeding laws, arrangements, and supports in Ethiopia limits mothers' right to practice optimal breastfeeding. Policymakers, the government, and all concerned bodies should give due attention to enacting and enforcing sound laws and arrangements that will enable employed mothers to practice optimal breastfeeding upon return to work.
\end{abstract}

Keywords: Breastfeeding, Employed mothers, Law, Ethiopia

* Correspondence: ermiyasmuller@gmail.com

College of Medicine and Health Science Ambo University, Ambo, Ethiopia

(c) The Author(s). 2021 Open Access This article is licensed under a Creative Commons Attribution 4.0 International License, which permits use, sharing, adaptation, distribution and reproduction in any medium or format, as long as you give appropriate credit to the original author(s) and the source, provide a link to the Creative Commons licence, and indicate if changes were made. The images or other third party material in this article are included in the article's Creative Commons licence, unless indicated otherwise in a credit line to the material. If material is not included in the article's Creative Commons licence and your intended use is not permitted by statutory regulation or exceeds the permitted use, you will need to obtain permission directly from the copyright holder. To view a copy of this licence, visit http://creativecommons.org/licenses/by/4.0/. The Creative Commons Public Domain Dedication waiver (http://creativecommons.org/publicdomain/zero/1.0/) applies to the data made available in this article, unless otherwise stated in a credit line to the data. 


\section{Background}

Optimal breastfeeding is the single most cost-effective intervention to reduce child mortality in developed and developing countries [1]. The impacts of breastfeeding on child mortality and morbidity, short-term and longterm child and maternal health, economic gain, and influence on future human capital development are well documented facts $[2,3]$. On this basis, World Health Assembly Member States in 2002 established exclusive breastfeeding and continued breastfeeding up to 2 years as the norm and the natural way to feed infants and young children [4].

Women's employment is one of the means for achieving the global effort of gender equality. Women empowerment interventions have positive impacts on child and maternal nutritional and health status [5]. Despite this fact, the changing composition of the workforce, especially women's increased participation rates, has made it a great challenge to find ways for breastfeeding to be compatible with work [6,7]. The International Labour Organization (ILO) indicated, returning to paid work is the main reason for the poor practice of breastfeeding among working mothers [8].

Suboptimal breastfeeding is among the main factors contributing to the high burden of child mortality, morbidity, and malnutrition in Ethiopia [9, 10]. Consistent evidence from diverse parts of Ethiopia indicated that maternal employment is often positively associated with suboptimal breastfeeding. Higher prevalence of nonexclusive breastfeeding, delayed breastfeeding initiation, and early cessation of breastfeeding were recorded among employed mothers compared to unemployed counterparts [11-15]. The progressing trend of women's employment and economic participation in Ethiopia entail adequate legal protection, arrangement, and support for breastfeeding in the work place [16]. This commentary compared the breastfeeding laws, policies, and arrangements in Ethiopia with international standards, recommendations, and evidence-based practices.

\section{Legal protection of breastfeeding in the workplace}

Different international, regional, and national laws protect motherhood and childhood worldwide. Enabling mothers to continue breastfeeding upon return to work is one of the essential elements of maternity protection. As early as 1919 , the ILO acknowledged that breastfeeding was an integral part of motherhood and reproduction and deserved protection at the workplace [17]. The ILO Convention No. 183 emphasizes that a working mother should be entitled to one or more daily breaks or a daily reduction of hours of work to breastfeed her child.
A woman shall be provided with the right to one or more daily breaks or a daily reduction of hours of work to breastfeed her child. (Convention No. 183, Article 10 (1). The period during which nursing breaks or the reduction of daily hours of work are allowed, their number, the duration of nursing breaks, and the procedures for the reduction of daily hours of work shall be determined by national law and practice. These breaks or the reduction of daily hours of work shall be counted as working time and remunerated accordingly. (Convention No. 183, Article 10 (2) [18].

Breastfeeding law, policies, and arrangements at the workplace should ensure optimal breastfeeding practice, work productivity, and women's right to equal work opportunity. Evidence shows that workplace breastfeeding arrangement and support for working mothers increase women's work motivation, attendance, satisfaction, and productivity and is essential to meet Infant and young child feeding (IYCF) standards of breastfeeding $[4,19]$.

\section{Importance of breastfeeding-friendly workplace policies in Ethiopia}

The breastfeeding right of most new mothers in Ethiopia is unprotected by public legislation and policies. The revised Labor Proclamation (No.1156/2019) incorporates most of the International Labour Organization maternity protection recommendation. However, it does not have specific legislation on breastfeeding protection and support in the workplace [20]. The revised Federal Civil Servant Proclamation of Ethiopia (No.1064/2017) enacts the establishment of a nursery in government institutions, where female civil servants could breastfeed and take care of their babies [21]. The Civil Servant Proclamation protects only a small proportion of working mothers in Ethiopia, as majority of women are employed in other sectors. Besides, we found poor implementation and enforcement of breastfeeding act under Proclamation No.1064/2017. As far as we witnessed, most of the government institutions do not have nursery facilities, and workplace breastfeeding arrangements and support for employed mothers by employers and other initiatives are nonexistent.

Maternity leave is one of the opportunities that will promote breastfeeding for working mothers [8]. The duration of maternity leave provided under Labor Proclamation (No.1156/2019) meets ILO's recommendation. However, the act has a narrow scope of maternity protection, as it does not cover most Ethiopian women employed in unpaid or underpaid agriculture sector and informal economy [22]. Unless the right to breastfeed is protected by additional act/s, the leave duration will not enable employed mothers to practice exclusive breastfeeding for 
6 months and continue up to 2 years, as recommended by international and national guidelines.

The ILO recommendation and experience of other middle- and low-income countries can be legal and practical grounds for establishment of breastfeedingfriendly workplace in Ethiopia [23]. For instance, Philippines enacted a national policy to encourage, protect and support the practice of breastfeeding in the workplace. The "Expanded Breastfeeding Promotion Act of 2009" of Philippines mandates all private enterprises and government agencies to support breastfeeding through workplace breastfeeding policy, provision of space and time for breastfeeding, provision of breastfeeding information in the workplace [24].

All employed women in Ethiopia have a right to practice optimal breastfeeding and deserve laws, arrangements, and support in the workplace. The law and policy options could include; adopting ILO breastfeeding conventions, introducing inclusive and explicit laws that protect all employed mothers' breastfeeding rights, and ensure implementation of the Federal Civil Servant Proclamation act. Besides, the involvement, mutual understanding, and coordination of all stakeholders are essential for establishing organizational, structural, and social arrangements of breastfeeding in the workplace. These emotional and physical arrangements could be made through initiatives like workplace awareness creation and promotion of breastfeeding, employer and colleague support of breastfeeding, the establishment of breastfeeding facilities and childcare centers, and flexible work arrangement etc. [25]. Although it might entail a detailed economic and cost-benefit analysis, extending the current maternity leave duration to 6 months might help exclusive breastfeeding.

\section{Conclusions}

The absence of breastfeeding laws, arrangements, and supports for employed mothers limits their ability and right to practice optimal breastfeeding. Policymakers, governments, and all concerned bodies should give due attention to enacting and enforcing sound laws and establishing arrangements and supports that will enable employed mothers to practice optimal breastfeeding upon return to work. Future researchers could focus on assessing the consequences of the problem and contextualizing and piloting different breastfeeding-friendly workplace interventions.

\section{Abbreviations}

CSA: Central Statistical Agency; EBF: Exclusive Breastfeeding; EDHS: Ethiopia Demography and Health Survey; FDRE: Federal Democratic Republic of Ethiopia; ILO: International Labour Organization/Office; IYCF: Infant and young child feeding
Authors' contributions

EM. participated in the study's conception and design, literature search analysis, and interpretation of findings and served as the manuscript's leading author. BS. participated in the literature search, analysis, and interpretation of results. Both authors read and approved the final manuscript.

\section{Funding \\ The authors did not receive financial support from organizations or individuals.}

\section{Availability of data and materials \\ Not applicable.}

\section{Declarations}

Ethics approval and consent to participate

Not applicable.

Consent for publication

Not applicable.

\section{Competing interests}

Authors declare they have no competing interests.

Received: 18 September 2020 Accepted: 8 June 2021

Published online: 14 June 2021

References

1. Black R, Victora C, Walker S, Bhutta Z, Christian P, Onis M, et al. Maternal and child undernutrition and overweight in low-income and middle-income countries. Lancet. 2013;382(9890):427-51. https://doi.org/10.1016/S0140-673 6(13)60937-X.

2. León-Cava N, Lutter C, Ross J, Martin L. Quantifying the benefits of breastfeeding : a summary of the evidence. Washington, D.C: Pan American Health Organization; 2002.

3. Victora CG, Bahl R, Barros AJ, França GV, Horton S, Krasevec J, et al. Breastfeeding in the 21st century: epidemiology, mechanisms, and lifelong effect. Lancet. 2016;387(10017):475-90. https://doi.org/10.1016/50140-6736(1 5)01024-7.

4. Fifty-Fourth World Health Assembly. Resolutions and decisions: Infant and young child nutrition. Geneva: World Health Organization; 2001. WHA54/ 2001/REC/1(WHA54.2): 1-5

5. Santoso MV, Kerr RB, Hoddinott J, Garigipati P, Olmos S, Young SL. Role of women's empowerment in child nutrition outcomes: a systematic review. Adv Nutr. 2019;10(6):1138-51. https://doi.org/10.1093/advances/nmz056.

6. Skafida V. Juggling work and motherhood: the impact of employment and maternity leave on breastfeeding duration: a survival analysis on growing up in Scotland data. Matern Child Health J. 2012;16(2):519-27. https://doi. org/10.1007/s10995-011-0743-7.

7. Kavle JA, LaCroix E, Dau H, Engmann C. Addressing barriers to exclusive breast-feeding in low- and middle-income countries: a systematic review and programmatic implications. Public Health Nutr. 2017;20(17):3120-34. https://doi.org/10.1017/S1368980017002531.

8. International Labour Office. Maternity at work: a review of national legislation / international labour office, conditions of work and employment branch. 2nd ed. Geneva: ILO; 2010

9. Adinew YM, Feleke SA, Mengesha ZB, Workie SB. Childhood mortality: trends and determinants in Ethiopia from 1990 to 2015: a systematic review. Adv Public Health. 2017;2017:7479295.

10. Nigatu D, Azage M, Motbainor A. Effect of exclusive breastfeeding cessation time on childhood morbidity and adverse nutritional outcomes in Ethiopia: analysis of the demographic and health surveys. PLoS One. 2019;14(10): e0223379. https://doi.org/10.1371/journal.pone.0223379.

11. Kebede T, Woldemichael K, Jarso H, Bekele BB. Exclusive breastfeeding cessation and associated factors among employed mothers in Dukem town Central Ethiopia. Int Breastfeed J. 2020;15(1):6. https://doi.org/10.1186/s13 006-019-0250-9.

12. Tadesse F, Alemayehu Y, Shine S, Asresahegn H, Tadesse T. Exclusive breastfeeding and maternal employment among mothers of infants from three to five months old in the Fafan zone, Somali regional state of 
Ethiopia: a comparative cross-sectional study. BMC Public Health. 2019;19: 1015. https://doi.org/10.1186/s12889-019-7345-5.

13. Chekol DA, Biks GA, Gelaw YA, Melsew YA. Exclusive breastfeeding and mothers ' employment status in Gondar town, Northwest Ethiopia : a comparative cross-sectional study. Int Breastfeed J. 2017;12:27.

14. Ahmed KY, Page A, Arora A, Ogbo FA. Trends and determinants of early initiation of breastfeeding and exclusive breastfeeding in Ethiopia from 2000 to 2016. Int Breastfeed J. 2019;14(1):40. https://doi.org/10.1186/s13006019-0234-9.

15. Hunegnaw MT, Gelaye KA, Ali BM. Factors associated with the time to cessation of breastfeeding among mothers who have index children aged two to three years in Debre Markos, Northwest Ethiopia: A retrospective follow up study. BMC Pediatr. 2018;18:77.

16. Central Statistical Agency - CSA/Ethiopia, ICF. Ethiopia Demographic and Health Survey 2016. Addis Ababa: CSA and ICF; 2017.

17. International Labour Office. Part XIII of the Treaty of Peace of Versailles: Labour. Official Bulletin. 1923:332-345.

18. International Labour Organization. Report form for the maternity protection CONVENTION, 2000 (No. 183). ILO Gender Network Handbook. Geneva; ILO, 2000.

19. Scott VC, Taylor YJ, Basquin C, Venkitsubramanian K. Impact of key workplace breastfeeding support characteristics on job satisfaction, breastfeeding duration, and exclusive breastfeeding among health care employees. Breastfeed Med. 2019;14(6):416-23. https://doi.org/10.1089/ bfm.2018.0202.

20. FDRE House of People's Representative. Labour Proclamation No.1156/2019. Federal Negarit Gazeta of The Federal Democratic Republic of Ethiopia. 2019; 25(89):11691-11792.

21. FDRE House of People Representative. Federal Civil Servants Proclamation No.1064/2017. Federal Negarit Gazeta of The Federal Democratic Republic of Ethiopia. 2017; 24(12):9979-10040.

22. International Monetary Fund. IMF country report No. 13/309. The Federal Democratic Republic of Ethiopia. Selected issues. Washington, D.C, USA; 2018.

23. Heymann J, Raub A, Earle A. Breastfeeding policy: a globally comparative analysis. Bull World Health Organ. 2013;91(6):398-406. https://doi.org/10.24 71/BLT.12.109363.

24. Congress of the Philippines. Republic Act No. 10028: Expanded Breastfeeding Promotion Act of 2009. Manila: Congress of the Republic of the Philippines; 2009

25. Maternity Protection Resource Package. From Aspiration to Reality for All, international labour office, conditions of work and employment Programme. Geneva: ILO; 2012.

\section{Publisher's Note}

Springer Nature remains neutral with regard to jurisdictional claims in published maps and institutional affiliations.

Ready to submit your research? Choose BMC and benefit from:

- fast, convenient online submission

- thorough peer review by experienced researchers in your field

- rapid publication on acceptance

- support for research data, including large and complex data types

- gold Open Access which fosters wider collaboration and increased citations

- maximum visibility for your research: over $100 \mathrm{M}$ website views per year

At $\mathrm{BMC}$, research is always in progress.

Learn more biomedcentral.com/submissions 